\title{
KONTRIBUSI WANITA HINDU DALAM PENERAPAN PROTOKOL KESEHATAN DI MASYARAKAT
}

\author{
Diah Nirmala Dewi, Ni Wayan Yusi Armini \\ UHN I Gusti Bagus Sugriwa Denpasar \\ nlu39they@yahoo.com, yusiarmini14@gmail.com
}

\begin{abstract}
The era new pandemi or what is often referred to as the new normal requires adapting to maintain physical and health during a pandemic like now. Almost all activities were carried out as before the beginning of the pandemic. There are many regulations that must be obeyed, there are many challenges for the community in doing activities in the new normal, always remember the health protocols using masks, maintaining distance when in public places, and implementing a healthy lifestyle. Women as mothers in the falimy who have to look after, care for, educate, with love so that everything becomes harmonious. Survive in the new normal period right for Hindu women to live according to the teachings of Hinduism in the Ayurweda book.
\end{abstract}

\section{Keywords: New Normal Era, Health Protocol, Hindu Women}

\begin{abstract}
Abstrak
Era tatanan baru atau yang sering disebut dengan new normal mengharuskan untuk beradaptasi dengan tetap menjaga kesehatan tubuh, dan mental di tengah masa pandemi seperti sekarang. Aktivitas sudah hampir semuanya berjalan seperti biasa sebelum virus covid19 menyerang. Begitu banyaknya peraturan yang harus ditaati, dan banyak juga tantangan yang harus dihadapi masyarakat dalam menjalankan aktivitas kehidupannya pada era new normal ini, diantaranya tetap dengan protokol kesehatan diantaranya menggunakan masker ketika bepergian keluar rumah, menjaga jarak dengan yang lain ketika berada di tempat umum dan menerapkan pola hidup sehat. Wanita sebagai Ibu dalam keluarga mengingat kodratnya yaitu menjaga, merawat, mendidik, dengan welas asih sehingga terjalin asah, asih, dan asuh. Bertahan hidup di era new normal tepat bagi wanita Hindu menerapkan pola hidup sehat sesuai ajaran - ajaran agama Hindu yang terdapat dalam Kitab Ayurweda.
\end{abstract}

\section{Kata Kunci : Era New Normal, Protokol Kesehatan, Wanita Hindu}

\section{Pendahuluan}

New Normal adalah suatu perubahan pola hidup masyarakat pada situasi COVID-19 (KepmenkesHK.01.07/MENKES/328/2020). Keberadaan pandemi Covid-19 berdampak sangat besar ke seluruh masyarakat dunia, dimana dampak tersebut tidak hanya mengarah pada bidang kesehatan, namun juga sosial-ekonomi. Di Indonesia, pemerintah dengan 
berbagai kebijakan berupaya untuk tetap menekan angka penularan Covid-19 dengan tetap fokus pada usaha perbaikan ekonomi negara (Aryawati, N. P. A., \& Negara, I. S. K., 2020). Dijelaskan bahwa New Normal merupakan kebijakan dari pemerintah untuk membuka kembali aktifitas ekonomi, aktifitas sosial dan kegiatan-kegiatan masyarakat umum yang masih dibatasi atau terbatas jumlah dan volume nya. Namun pembukaan tersebut dengan syarat tetap menggunakan protokol kesehatan yang ditetapkan oleh pemerintah. Pada situasi seperti saat ini, tempat kerja perkantoran, sekolah, industri, sektor jasa dan perdagangan akan mulai dibuka perlahan, dan untuk mendukung keberlangsungan masa ini untuk memajukan perekonomian tetap memperhatikan protokol kesehatan yang ditetapkan oleh Pemerintah, yang tentu diawasi oleh aparat TNI/Polri, pecalang di desa adat setempat.

Pada tanggal 15 Mei 2020, istilah New Normal ini muncul di Indonesia setelah pada saat itu Presiden RI Ir. Joko Widodo menegaskan bahwa masyarakat Indonesia harus bisa berkompromi dengan keadaan saat ini, hidup berdampingan, dan berdamai dengan Covid-19 agar tetap produktif. Pada tanggal 20 Mei 2020, pemerintah pusat yang melalui Kemenkes mengeluarkan; Kepmenkes No. HK.01.07/Menkes/328/2020 tentang panduan pencegahan dan Covid-19 di tempat kerja perkantoran dan industri dalam mendukung keberlangsungan usaha pada situasi pandemi surat edaran Nomor HK.02.01/MENKES/335/2020 tentang protokol pencegahan penularan Covid-19 di tempat kerja sektor jasa dan perdagangan (Area Publik) dalam mendukung keberlangsungan usaha hingga surat edaran HK.02.01/ MENKES/ 334/2020 tentang protokol pencegahan penularan Covid-19 bagi aparat yang melaksanakan tugas pengamanan dan penertiban dalam rangka percepatan penanganan Covid-19. Kebijakan - kebijakan pemerintah sudah di edarkan ke daerah dan sudah mulai di terapkan. Dalam hal ini juga peran perempuan dalam protocol kesehatan juga penting, mulai dari memperhatikan protocol kesehatan di keluarga.

Peran wanita yang harus bisa membagi waktu dan juga fokus antara menjadi seorang pembimbing bagi anak pada saat diri nya bersekolah di rumah (SFH), kemudian wanita juga mengurus pekerjaan rumah tangga, berkarier juga merupakan pilihannya, sekaligus juga menjadi pelindung kesehatan bagi keluarganya yang harus selalu diperhatikan. Pada situasi seperti ini dapat membuat seorang ibu merasa kewalahan dengan berbagai kewajiban yang harus di perhatikan, sehingga rentan terhadap gangguan kesehatan tubuh dan juga beban mental. Di tengah situasi yang tidak pasti seperti ini, mudah bagi siapapun untuk merasakan 
lelah tubuh maupun pikiran. Terutama bagi wanita yang sudah menjadi seorang ibu yang berperan sebagai tonggak keluarga. Sebagai seorang wanita Hindu dan sekaligus menjadi ibu dari anak, saya sendiri juga merasakan ada tantangan yang lebih dalam menyeimbangkan peran saya sebagai ibu yang juga harus bekerja, kemudian membimbing anak, dan menjadi pelindung kesehatan bagi keluarga di masa adaptasi baru seperti sekarang yang sering disebut era new normal.

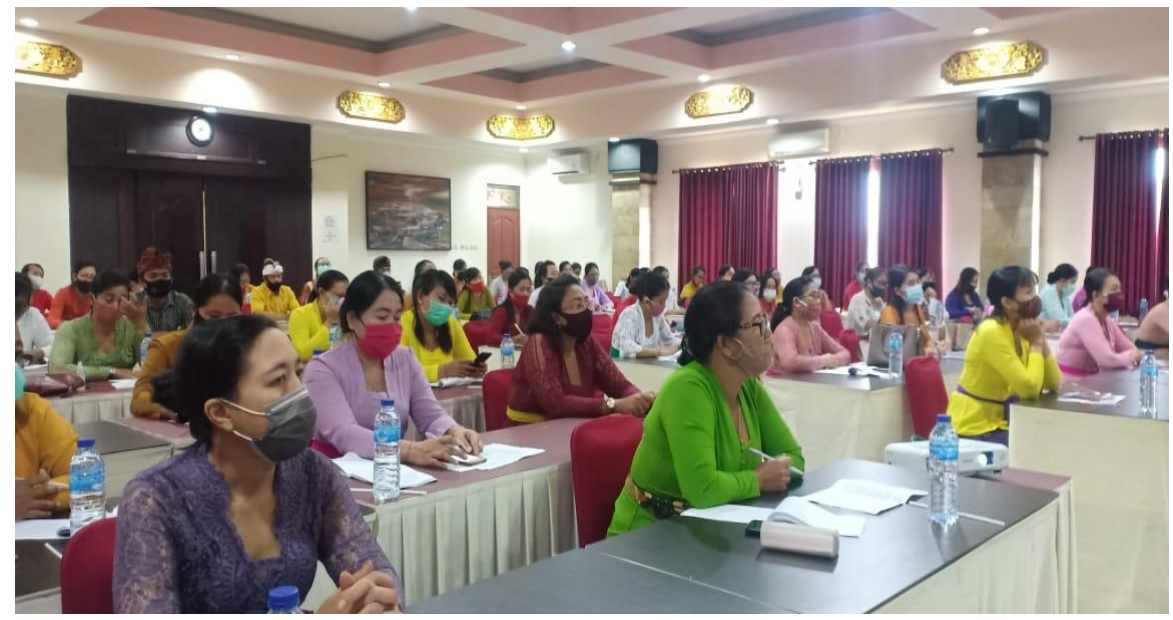

Gambar 1 : Pelatihan Guru - guru Pendidikan Anak Usia Dini (PAUD) di Hotel Puri Nusa Indah Denpasar yang pesertanya dominan wanita (Wanita Hindu).

\section{Hasil dan Pembahasan}

\section{Wanita Hindu}

Wanita berasal dari Bahasa Sanskrit, yaitu Svanittha, di mana kata Sva artinya "sendiri" dan Nittha artinya "suci". Jadi Svanittha artinya "mensucikan sendiri" kemudian berkembang menjadi pengertian tentang manusia yang mempunyai peran penting di dalam Dharma atau disebut sebagai "pengamal Dharma". Dari penjelasan tersebut maknanya berubah menjadi Sukla Svanittha yang artinya "bibit" atau "janin" yang dikandung oleh manusia, dalam hal ini yang merupakan peranan sebagai perempuan. Wanita sangat diperhatikan sebagai penerus keturunan dan sekaligus "sarana" terwujudnya Punarbhawa atau reinkarnasi (kelahiran kembali), sebagai salah satu sradha (kepercayaan/keyakinan) dalam agama Hindu. Sejak mengalami menstruasi pertama, seorang wanita sudah dianggap dewasa, dan juga merupakan ciri/tanda bahwa seorang wanita mempunyai kemampuan untuk hamil. Oleh karena itu 
peradaban lembah sungai Indus di India sejak beribu tahun lampau senantiasa menghormati dan memperlakukan seorang wanita secara hati-hati terutama ketika wanita tersebut menstruasi.

Wanita yang sedang menstruasi dijaga tetap berada di dalam kamar agar terlindung dari mara bahaya. Lihatlah kisah Mahabharata ketika Drupadi, istri Pandawa yang sedang menstruasi menjadi korban taruhan kekalahan berjudi Dharmawangsa dari Pandawa melawan Sakuni di pihak Korawa. Drupadi yang diseret keluar dan coba ditelanjangi oleh Dursasana di depan sidang. Dewa Dharma melindungi Drupadi sehingga kain penutup badan Drupadi tidak habis - habis, tetap melindungi tubuhnya walau bermeter-meter telah ditarik darinya. Sejak awal Drupadi sudah mengingatkan Dursasana, bahwa diri nya sedang haid, tidak boleh diperlakukan kasar dan dipaksa demikian. Akhirnya dalam perang Bharatayuda, Dursasana dibinasakan Bima, dan Drupadi menebus kaul dengan mencuci rambutnya dengan darah Dursasana. Wanita yang sedang menstruasi harus diperlakukan khusus karena di saat itu diri nya memerlukan ketenangan fisik dan mental.

Namun perkembangan tradisi beragama Hindu di Bali menjadi berbeda, seperti yang disebutkan didalam Lontar Catur Cuntaka, bahwa wanita yang sedang haid tergolong "cuntaka" atau "sebel" atau dalam bahasa sehari-hari disebut "kotor", sehingga ia dilarang sembahyang atau masuk ke Pura. Ini perlu diluruskan sesuai dengan filosofi Hindu yang benar. Stri disebut sebagai pengamal "Dharma" dan suami disebut sebagai pengamal "Shakti". Peranan istri dapat dikatakan sebagai pengamal Dharma, karena hal-hal yang dikerjakan seperti: mengandung, melahirkan, memelihara bayi atau anak - anaknya, dan seterusnya mengajar dan mendidik anak-anak, mempersiapkan upacara-upacara agama Hindu di lingkungan rumah tangga, menyayangi suami, merawat mertua. Peranan suami dapat dikatakan sebagai pengamal Shakti, karena dengan kemampuan pikiran dan jasmani bekerja mencari nafkah untuk kehidupan rumah tangganya. Kombinasi antara Dharma dan Shakti ini menumbuh kembangkan dinamika kehidupan. Oleh karena itu pula istri disebut sebagai "Pradana" yang artinya pemelihara, dan suami disebut sebagai "Purusha"artinya penerus keturunan. Adapun dalam kitab suci agama Hindu menyebutkan sifat-seorang wanita di antaranya: Sifat-sifat wanita yang patut ditumbuh kembangkan adalah sebagai perintis (pelopor). Cermerlang, pendukung, (meringankan tugas suami), memberi/menyunguhkan makanan, menjalankan dharma sebagai ibu pertiwi. Seorang wanita dituntut menjalankan 


\section{SOPHIA DHARMA, Vol 4, No 1, Mei 2021}

kesopanan (ketika berjalan dan duduk), cerdas (mampu menjadi sarjana) dan sebagai guru (pembimbing).

\section{Kedudukan Wanita Hindu}

Kedudukan wanita dalam teks-teks Hindu sangat berbeda. Hinduisme memberikan kedudukan yang tertinggi kepada Dewi (aspek perempuan Dewa) dan pada masa yang sama membebankan/membagi peranan wanita itu kepada seorang anak, isteri dan sebagai ibu. Dewi Sukta dalam Rg. Weda mengumumkan bahwa tenaga kewanitaan sebagai unsur alam semesta ini, pencipta dan kesadaran, abadi yang meliputi segala - galanya, kebenaran yang metafisik dan empirik. Wanita juga diberikan kedudukan sebagai seorang yang kuasa yang hebat dan kuat dalam beberapa kitab Hindu yaitu pada Upanishad, Sastra, dan Purana, terutama dalam Devi Upanishad, Devi Mahatmya dan Devi Bhagavata Purana. Istri dipanggil sebagai ardhangini (secara literal bermaksud 'separuh badan'). Suami-istri dianggap sebagai dua bagian dari satu perkahwinan yang ideal. Istri juga disebut sebagai sahadharmini yang bermaksud "berfungsi dalam kehidupan rohani". Suami istri harus bekerjasama untuk mencapai perkembangan kerohanian yang seimbang. Wanita sebagai seorang individu di dalam masyarakat Aryan diingatkan tentang tujuan akhir hidup yaitu kesadaran terhadap Tuhan pada setiap tahap hidupnya.

Kedudukan wanita dalam kitab - kitab suci agama Hindu di antara nya: Wanita Hindu pada zaman Rg. Weda diberikan penghormatan tinggi dalam keluarga sebagai ibu dan istri. Golongan wanita juga diberikan kebebasan untuk mendapatkan pendidikan tinggi. Malah, dalam kalangan Rshi-rshi juga terdapat wanita-wanita (dinamakan sebagai 'Rishika'). Rg.Weda sendiri mempunyai hampir 30 Rishika. Wanita Hindu pada zaman Mahabharata, zaman klasik India memaparkan sebuah keadaan masyarakat Hindu dalam zaman Dwapara. Pada zaman ini melibatkan kisah Drupadi, istri dari lima bersaudara putra Pandawa. Teks Mahabharata sendiri memberikan berbagai reaksi yang bertentangan dengan perkawinan yang ideal. Menjadi seorang istri dari kakak-adik saudara kandung lebih dari satu dikenal sebagai poliandri. Zaman Mahabharata mengajarkan tentang Dharma atau etika seorang lelaki seperti berikut: Walaupun dalam keadaan marah, seorang lelaki tidak patut melakukan sesuatu yang membuat sedih atau sakit istrinya kerana kebahagiaan, kegembiraan, kebaikan dan segalagalanya bergantung kepada istrinya. Wahai raja, menurut kitab - kitab suci Hindu, seorang 
anak perempuan adalah setaraf dengan seorang anak lelaki. Sita merupakan ideal dalam wanita Hindu. Kausalya, Sumitra, Tara, Mandodari, Sabari, dan Kaikeyi adalah antara wanita - wanita hebat yang disebut pada zaman ini.

Menurut ajaran Agama Hindu bahwa wanita di porsikan memiliki kedudukan yg terhormat sesuai kodratnya seperti yg di uraikan dalam Manawa Dharma sastra III.55-58 sebagai berikut :

" pitrbhir bhratrbhis caitah patibhir dewa raistatha pujya bhusayita wyasca bahu kalyanmipsibhih (M.Ds.III.55). yatra naravatsu pujyante ramante tatra devatah yatraitastu na pujyante sarvastalah kriyah (M.Ds.III.56). socanti jamayo yatra winasyatyacu tatkulam na socanti tu yatraita wardhate tadhi sarvada" (M.Ds.III.57). " jamayo yani gehani capantya patti pujitah tani krtyahataneva winasyanti samantarah" (M.Os.III.58).

Artinya :

"wanita harus dihormati dan disayangi oleh ayahnya, kakaknya, suami dan ipar-iparnya, jika menghendaki kesejahteraan. Dimana wanita dihormati,disanalah para Dewa merasa senang, tetapi dimana mereka tidak dihormati, tidak ada upacara suci apapun dalam keluarga itu berpahala. Dimana warga wanitanya hidup dalam kesedihan,keluarga itu cepat akan hancur, tetapi di mana wanita itu tidak menderita, keluarga itu akan selalu bahagia. Rumah dimana wanitanya tidak di hormati sewajarnya, mengucapakan katakata kutukan, keluarga itu akan hancur seluruhnya seolah - olah di hancurkan oleh kekuatan gaib. Dalam kutipan diatas dapat kita simpulkan bahwa kedudukan seorang wanita dalam Hindu sangat tinggi dan terhormat." (Manawadharmasastra,III. $55,56,57,58)$.

Masalah kesetaraan atau kedudukan wanita dalam agama Hindu di tuliskan dalam sloka sebagai berikut:

"Murdha asi rad dhruva asi, Dharuna dharti asi dharani, Ayusve tvavarcasetva, Krisyaitva ksemaya tva." (Yajurveda XIV.21).

Artinya: "Wahai perempuan engkau adalah perintis cemerlang, mantap, pendukung yang memberi makan dan menjalankan aturan - aturan, kami memiliki engkau di dalam keluarga untuk usia panjang, kecemerlangan, kemakmuran, kesuburan pertanian dan kesejahteraan.” (Titib, 2003:416).

" Ksetrabhuta smrta nari bijabhutah smrtah puman, ksetrabija samayogat sambhawah sarwa dehinam." (Manawadharmasastra IX.33).

Artinya : 


\section{SOPHIA DHARMA, Vol 4, No 1, Mei 2021}

"Menurut Smrti bahwa perempuan diumpamakan sebagai tanah, laki - laki dinyatakan sebagai benih / bibit, hasil terjadinya jasad badaniah yang hidup terjadi karena melalui hubungan antara tanah dengan benih.” (Pudja dan Sudharta, 2003:534)

\section{Kontribusi Wanita Hindu Dalam Penerapan Protokol Kesehatan}

Regenarasi kehidupan dapat dijaga eksistensinya berkat adanya perempuan sebagai pasangan laki-laki dalam melakukan reproduksi atau menghasilkan keturunan sehingga perempuan mempunyai kontribusi yang besar didalamnya. Demikian pula dalam agama Hindu, seorang wanita pada agama Hindu dipandang sebagai kaum yang memiliki peran tidak terpisahkan dengan kaum pria pada kehidupan di masyarakat dari jaman ke jaman. Sejak awal peradaban agama Hindu yaitu dari jaman Weda hingga saat ini seorang wanita senantiasa memegang peran penting di dalam kehidupan. Hal ini tidak mengherankan dilihat dari konsepsi ajaran agama Hindu dalam Siwa Tattwa yang menyebutkan adanya kehidupan makhluk terutama manusia karena adanya perpaduan antara unsur sukla dan swanita. Tanpa wanita tidak mungkin ada dunia yang harmonis.

Demikian pentingnya kedudukan wanita dalam kehidupan khususnya dalam agama Hindu. Pernyataan di atas memberikan penegasan kebenaran atas idealisme tentang keutamaan wanita ini seharusnya menjadi landasan perjuangan bagi kaum wanita dewasa ini untuk menumbuh kembangkan kemuliaannya ditengah-tengah masyarakat yang beradab. Dalam peradaban Veda semua wanita dihormati sebagai ibu yang memiliki sifat-sifat kedewasaan. Karena kemuliaan seorang ibu memiliki kualifikasi kasih sayang yang memungkinkan diri nya mendidik dan membesarkan anak-anaknya dengan penuh kasih sayang. Berdasarkan dari uraian diatas, maka peran dan tanggung jawab wanita yang patut ditumbuh kembangkan adalah sebagai perintis (pelopor), yang berkepribadian cemerlang, pembimbing yang penuh kasih sayang dalam keluarga, pendidik yang berkualifikasi sarjana guna mencetak generasi yang cakap dan berkepribadian yang luhur dan bahkan sebagai generasi penerus bangsa yang akan membawa kemajuan untuk negeri ini.

Dalam Hindu memandanng bahwa wanita karir adalah hak asasi sepanjang tidak meninggalkan kodratnya sebagai wanita. Menjadi wanita karir bukan berarti boleh tidak setia dan tidak menghormati suami dan tidak mengurus anak, anggapan ini salah besar. Memang wanita dihadapkan kepada hal yang sangat dilematis karena keadaan fisik yang secara kodrati 
lebih lemah dari laki-laki dan disisi yang lain dia harus taat kepada kodratnya. Berkenaan dengan kesetaraan gender ini harus disikapi secara arif dan bijaksana, artinya kasuistis tidak bisa dijadikan ukuran bahwa wanita kedudukannya sebagai second class apalagi outclass. Pada hakekatnya wanita harus mampu mengkolaborasikan karir atau pekerjaan dengan urusan rumah tangga bila diri nya telah memilih untuk menjadi wanita karir.

Badan Pusat Statistik (BPS) merilis survei mengenai perilaku masyarakat di masa pandemi Covid-19. Dari hasil survei, responden wanita relatif lebih patuh protokol kesehatan ketimbang pria. Adapun, survei dilakukan pada 7-14 September dengan total 90.967 responden. Dari jumlah tersebut, sebanyak 55,23\% merupakan wanita dan 44,77\% laki-laki. Perempuan jauh lebih patuh dibandingkan laki-laki ketika menerapkan protokol 3M (memakai masker, menjaga jarak, mencuci tangan). Dalam hal ini dapat menjelaskan bahwa dalam pelaksanaan kebijakan New Normal, wanita memiliki kontribusi besar dalam upaya menjaga protocol kesehatan. Menurut Noorzeha (2020), New Normal ini akan mengarahkan pada pola kehidupan yang baru. Dimana upaya menuju hal tersebut dibutuhkan pembiasaan, kedisiplinan, dan ketertiban.

Wanita Hindu tetap memakai konsep sehat sesuai ajaran agama Hindu yang berkaitan dengan Tri Kaya Parisuda, ditengan menyebarnya virus Covid-19 menyadarkan masyarakat Hindu khususnya di Bali pentingnya hidup secara seimbang dalam arti mempelajari kembali dan menerapkan hidup sehat sesuai kitab pengobatan dalam agama Hindu yaitu Ayurweda untuk keselarasan fisik, pikiran, dan spiritual yang tidak hanya diterapkan pada diri sendiri tetapi juga pada alam sekitar. Ayurweda merupakan kitab pengobatan agama Hindu yang ada sejak 5000 tahun SM. Kitab Ayurweda dianggap sebagai ilmu pengetahuan tentang hidup atau the science of life dan dianggap sebagai metode pengobatan di dunia barat. Kitab Ayurweda juga dijelaskan bahwa ilmu - ilmu pengobatan yang di ajarkan bersifat dinamis, tidak ada satu ilmunya yang sempurna sehingga saling memperbaiki dengan ilmu - ilmu pengobatan lain sejalan dengan waktu. Karena sifatnya terbuka dan universal membuat banyak peminat dalam mempelajari kitab Ayurweda.

Di dalam kitab Ayurweda dijelaskan bagaimana tubuh dan alam semesta pada kesehatan. biasa saling berpengaruh Rsi Caraka mengartikan kitab Ayurweda dapat menolong seseorang untuk mendapatkan ilmu pengetahuan tentang manfaat serta bahaya macam macam kehidupan. Dalam kitab Ayurweda tidak hanya mebahas keseimbangan organ tubuh, 


\section{SOPHIA DHARMA, Vol 4, No 1, Mei 2021}

psikoloi serta spiritual, keseimbangan alam semesta yang sangat membawa pengaruh pada kehidupan manusia juga di bahas yang sejalan dengan ajaran Tri Kaya Parisuda yaitu berpikir, berkata, dan berbuat baik. Konsep sehat secara seimbang menjaga pola makan, mengatur kondisi psikis tetap sehat dan penyelarasan diri dengan spiritual sudah didasari sejak ribuan tahun lalu. Sehingga di tengah pandemi mampu menyeimbangkan diri agar tetap sehat dan bahagia. Tertulis sebagai berikut :

"Sarve bhavantu sykhinah sarve santu niramayah sarve bhadani pasyantu haa kascit duhkhabhak bhavet", yang artinya : semoga semua bahagia, semoga semua bebas dari ketidakmampuan, semoga semua menatap kebaikan yang lain, semoga tidak menderita kesedihan.

" Apatyam dharmakaryani susrousa ratiruttama, daradhinastatha svargatah pitrir nanatmanascha ha." (manawadharmasastra IX.28). yang artinya : Anak - anak, upacara agama, pengabdian/kepatuhan, kebahagiaan rumah tangga, sorga untuk leluhur maupun untuk diri sendiri semuanya didukung oleh perempuan. (Pudja dan Sudharta, 2003:533).

"Patim ya nabhicarati manovag dehasamyata, sa bhartr lokanapnoti sadbhih sadhviti cocyate." (manawadharmasastra IX.29). yang artinya: Wanita yang mengendalikan pikiran, perkataan, dan perbuatannya yang tidak melanggar kewajiban terhadap keluarga akan mendapatkan tempat yang mulia bersama-sama di sorga yang disebut sadhwi istri yang mulia. (Pudja dan Sudharta, 2003:533)

Wanita Hindu mengaplikasikan ajaran - ajaran agama dalam menghadapi masa peralihan seperti sekarang yang di sebut dengan era new normal, selain isi yang termuat dalam kitab Ayurweda bersifat universal namun sesuai dengan tujuan hidup manusia yang beragama Hindu pada ajaran catur purusa artha yaitu; Dharma yang artinya kebenaran dan kebaikan, Artha yang artinya kekayaan untuk memenuhi kebutuhan hidup, Kama yang artinya nafsu yang perlu disalurkan secara baik, dan yang terakhir Moksa yang artinya pembebasan yang membawa kesadaran hidup yang lebih baik. : https://hindualukta.blogspot.com/2015/09.

\section{Kesimpulan}

Demikian pentingnya kedudukan wanita dalam kehidupan khususnya dalam agama Hindu. Pernyataan di atas memberikan penegasan kebenaran atas idealisme tentang keutamaan wanita ini seharusnya menjadi landasan perjuangan bagi kaum wanita dewasa ini untuk menumbuh kembangkan kemuliaannya ditengah-tengah masyarakat yang beranekaragam. Dalam peradaban Weda semua wanita dihormati sebagai ibu yang memiliki 
sifat-sifat kedewasaan. Karena kemuliaan seorang ibu memiliki kualifikasi kasih sayang yang memungkinkan dia mendidik dan membesarkan anak-anaknya dengan penuh kasih sayang. Berdasarkan dari uraian di atas, maka peran dan tanggung jawab wanita yang patut ditumbuh kembangkan adalah sebagai perintis (pelopor), yang berkepribadian cemerlang, pembimbing yang penuh kasih sayang dalam keluarga, pendidik yang berkualifikasi sarjana guna mencetak generasi yang cakap dan berkepribadian yang luhur dan bahkan sebagai generasi penerus bangsa yang akan membawa kemajuan untuk negeri ini. Dalam Hindu memandang bahwa wanita karir adalah hak asasi sepanjang tidak meninggalkan kodratnya sebagai wanita.

Wanita Hindu tetap memakai konsep sehat sesuai ajaran agama Hindu yang berkaitan dengan Tri Kaya Parisuda, ditengah menyebarnya virus covid-19 menyadarkan masyarakat Hindu khususnya di Bali pentingnya hidup secara seimbang dalam arti mempelajari kembali dan menerapkan hidup sehat sesuai kitab pengobatan dalam agama Hindu yaitu Ayurweda untuk keselarasan fisik, pikiran, dan spiritual yang tidak hanya diterapkan pada diri sendiri tetapi juga pada alam sekitar. Wanita Hindu mengaplikasikan ajaran - ajaran agama Hindu dalam menghadapi masa peralihan seperti sekarang yang di sebut dengan era new normal, selain isi yang termuat dalam kitab Ayurweda yang bersifat universal namun juga sesuai dengan tujuan hidup manusia yang beragama Hindu pada ajaran catur purusa artha yaitu; Dharma yang artinya kebenaran dan kebaikan, Artha yang artinya kekayaan untuk memenuhi kebutuhan hidup, Kama yang artinya nafsu yang perlu disalurkan secara baik, dan yang terakhir Moksa yang artinya pembebasan yang membawa kesadaran hidup yang lebih baik.

\section{Daftar Pustaka}

Aryawati, N. P. A., \& Negara, I. S. K. (2020). COVID-19: KEBIJAKAN STRATEGIS DALAM MENANGANI DAMPAK SOSIAL EKONOMI DARI SISI BIAYA TIDAK LANGSUNG DI INDONESIA. Sophia Dharma: Jurnal Filsafat Agama Hindu dan Masyarakat, 3(1), 1-11.

Noorzeha, F. (2020). NEW NORMAL AS THE NEW HUMAN: MASA PANDEMI DALAM PERSPEKTIF FILSAFAT MANUSIA SÖREN AABYE KIERKEGAARD DAN RELEVANSINYA PADA KEHIDUPAN MANUSIA MASA DATANG. Sophia Dharma: Jurnal Filsafat Agama Hindu dan Masyarakat, 3(2), 1-16. 
Pudja, G., \& Sudharta, T. R. (2003). Manawa Dharmaśastra (Manu Dharmaśastra) atau Weda Smrti Compendium Hukum Hindu.

Subali, Ida Bagus. (2008). Wanita Mulia Istana Dewa. Paramita: Surabaya.

Suryani, Luh Ketut. (2003). Perempuan Bali Kini. BP: Denpasar.

Wirawan, I Wayan Ardhi. (2015). Makalah Pendidikan Perempuan Menurut Ajaran Hindu dan Dalam Praktik Budaya Bali. STAHN Gde Pudja: Mataram.

Saridewi, Desak Putu. (2014). Artikel Desain Diri Bagi Wanita Hindu Pada Era Modern Di Nusa Tenggara Barat. STAHN Gde Pudja: Mataram.

https://hindualukta.blogspot.com/2015/09 